Крикун П. М.;

Наливайко А. Д., к.т.н., доцент;

Поляєв А. I.

Центр воєнно-стратегічних досліджень Національного університету оборони України імені Івана Черняховського, Київ

\title{
Впровадження в оборонному плануванні складових сил оборони сучасної методології оцінювання спроможностей
}

Резюме. У статті розглянуто можливі підходи до здійснення процедури оцінювання спроможностей складових сил оборони у межах оборонного планування на основі спроможностей 3 урахуванням вітчизняного досвіду оборонного планування та досвіду держав-членів НАТО.

Ключові слова: оборонне планування на основі спроможностей; оцінювання спроможностей; базові елементи (складові) спроможностей; система управління вимогами.

Постановка проблеми. Відповідно до стратегічної цілі 2 Стратегічного оборонного бюлетеня України (СОБ) питання удосконалення оборонного планування на основі спроможностей (ОПОС) стало одним 3 ефективних підходів до визначення пріоритетів розвитку сил оборони. Ключовим елементом процесу проведення ОПОС $\epsilon$ процедура оцінювання спроможностей. Впровадження у практику оборонного планування аналітичних процедур оцінювання спроможностей робить систему планування ефективнішою i наближає ऑii до стандартів НАТО.

Кардинальна зміна пріоритетів припід час переходу від існуючої системи оборонного планування (ОП) до планування на основі спроможностей 3 орієнтацією іiі на кращі європейські стандарти має стати основою реформування системи оборонного планування національних сил оборони. Зазначене актуалізує питання підвищення ефективності оборонного планування у силах оборони через впровадження процедури оцінювання спроможностей за методологією, яка основана на євроатлантичних принципах $\mathrm{i}$ підходах.

Ступінь розробленості проблеми. Упродовж останніх років у МО та ЗС України розроблено низку нормативно-правових актів 3 оборонного планування на основі спроможностей, опрацьовуються та впроваджуються новітні підходи до оцінювання спроможностей [1-4]. Цій проблематиці також присвячено низку наукових досліджень, зокрема I. Руснака, Р. Тимошенка, Н. Дєнєжкіна, В. Корендовича, П. Крикуна, Ф. Саганюка та інших [5-10], де аналізуються підходи, методики i моделі оборонного планування 3 урахуванням спрямованості України на подальшу Євроатлантичну інтеграцію. Водночас у цих наукових працях недостатньо уваги приділяється питанням розроблення методологічної бази ОПОС, формуванню та детальному опису процедур процесу планування, зокрема, i оцінюванню спроможностей складових сил оборони.

Мета статті - впровадження в оборонному плануванні складових сил оборони сучасної методології оцінювання спроможностей.

Виклад основного матеріалу. Найактуальнішим питанням щодо розвитку оборонного планування у складових сил оборони є адаптування методології оцінювання спроможностей, яка застосовується в державах-членах НАТО до національних особливостей України.

Відповідно до змісту зазначеної методології щодо оцінювання спроможностей, основним ii завданням має бути визначення (уточнення) вимог до спроможностей; порядок ідентифікації недоліків/проблем, що виникають; підготовка та надання рекомендацій щодо усунення (вирішення) визначених недоліків/проблем для досягнення необхідних спроможностей відповідно до їх базових елементів, зокрема доктринальної складової, організації, підготовки, ресурсного забезпечення, якості управління та освіти, персоналу, військової інфраструктури, сумісності тощо [4].

Оцінювання наявних спроможностей має включати:

виявлення нових викликів i загроз воєнній безпеці України, які визначатимуть потребу в змінах або удосконаленні через 
процес оцінювання відповідних спроможностей складових сил оборони;

опис розвитку та застосування спроможності в існуючому стані структурної побудови складових сил оборони;

обгрунтування потреб щодо забезпечення розвитку спроможностей, які визначаються зважаючи на рівень загроз в існуючому та майбутньому безпековому середовищі;

опис спроможностей у контексті бажаного кінцевого стану, шляхів досягнення поставлених цілей (виконаних заходів) і засобів щодо забезпечення виконання спроможностей;

визначення та розроблення відповідних національних керівних документів щодо розвитку спроможностей.
Особливістю такого оцінювання буде те, що воно здійснюватиметься на рівні складових сил оборони i матиме вибірковий характер об'єктів оцінювання (складових спроможностей). Такий підхід дасть змогу зосередитися на усуненні (вирішенні) ключових (критичних) недоліків/проблем під час розподілу пріоритетності програмних заходів і державних ресурсів.

Незважаючи на вибірковий характер складових спроможностей у процесі оцінювання має проводитись аналіз значного масиву даних i розрахунків, який потребує значних витрат ресурсів і часу. Оцінювання спроможностей складових сил оборони доцільно здійснювати у логічній послідовності (алгоритму) аналітичних елементів процедури, яка загалом може бути представлена блоксхемою (рис. 1).

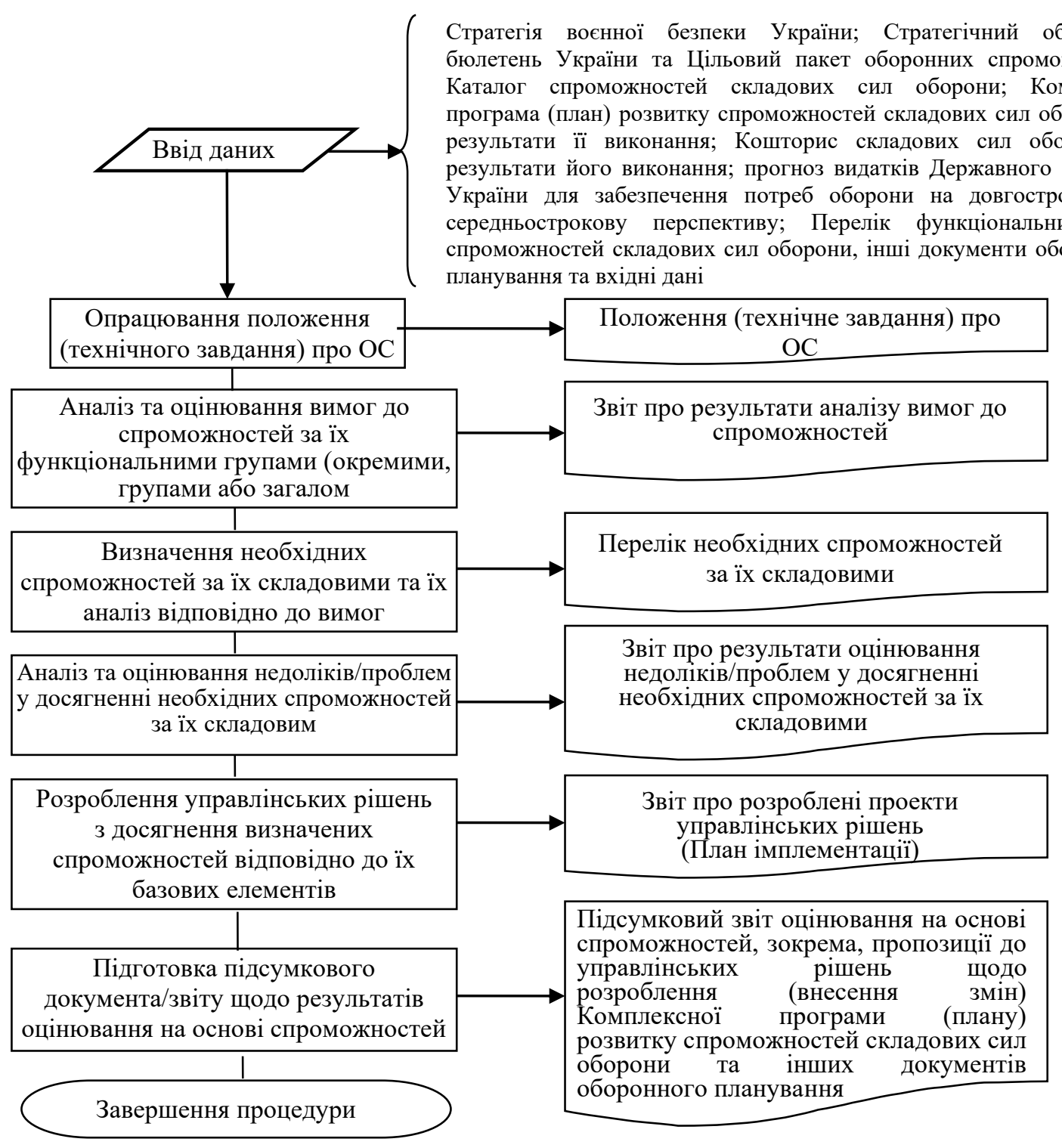

Рис. 1. Структурна блок-схема проведення оцінювання спроможностей 
Аналіз логічної послідовності виконання заходів процедури оцінювання спроможностей у складових сил оборони дає змогу дійти висновку, що для досягнення системності процесу оцінювання до його складу доцільно включити такі аналітичні елементи (етапи): відпрацювання Положення про оцінювання спроможностей (технічне завдання ОС), яке містить організаційні питання щодо створення робочих груп, масштаби аналізу або обсяг напрямів діяльності об'єктів планування, порядок затвердження програм/планів роботи на всіх аналітичних етапах тощо;

аналіз вимог, який включає визначення (уточнення): вимог до спроможностей, конкретні завдання, умови, характеристики та показники результативності складових спроможностей за його елементами (доктринальна складова, організація, підготовка, ресурсне забезпечення, якість управління та освіта, персонал, військова інфраструктура, сумісність);

визначення необхідних спроможностей та їх аналіз відповідно до вимог здійснюється за кожною спроможністю за іiі окремими складовими (елементами) - здійснюється оцінка частин і підрозділів ЗС України та інших складових $\mathrm{CO}$, окремі основні зразки (системи) ОВТ тощо, які $є$ носіями спроможностей;

аналіз недоліків/проблем, що передбачає оцінювання необхідних спроможностей i визначення різниці між необхідними та наявними спроможностями, виявлення надлишкових/зайвих спроможностей;

аналіз рішень, а саме розроблення управлінських рішень щодо підтримки, нарощування, створення або позбавлення зайвих спроможностей відповідно до базових складових спроможностей за його елементами;

розроблення документів, як заключний етап оцінки, що передбачає підготовку загального звіту та уточнення Цільового пакету спроможностей сил оборони, планів розвитку спроможностей складових сил оборони та інших документів.

Згідно $з$ поглядами фахівців з ОПОС важливим документом оцінювання спроможностей $\epsilon$ Положення про ОС (технічне завдання ОС). Його доцільно розробляти для кожної процедури оцінювання 3 врахуванням специфіки (умов) його проведення.

Цей документ має надати відповіді на такі питання:

У чому полягає зміст та мета оцінювання спроможностей? і коли?

Яких результатів передбачається досягти

Хто і яким чином розглядатиме та схвалюватиме рекомендації?

Яка роль кожної структури/організації під час проведення оцінювання спроможностей і поданні результатів?

Яким чином зменшити непорозуміння між учасниками процесу оцінювання спроможностей i які їхні рамкові повноваження?

Як буде проводитися оцінювання спроможностей (за якою методологією), які етапи 3 огляду на завдання, заходи та результати?

Які ключові визначення, нові терміни, ідеї, припущення, що визначатимуться як прийнятні (стандартні)?

Також у Положенні визначається i детальний підхід та часові рамки для оцінювання спроможностей, висвітлюються ключові контрольні точки послідовної роботи учасників процесу оцінювання. Відповідно до контрольних точок визначається порядок подання проміжних і кінцевих результатів (доповідей, звітів, документів тощо).

Першочерговим аналітичним етапом оцінювання спроможностей $є$ етап аналізу вимог, який передбачає: формування вимог до спроможностей, які визначаються законодавчими актами, стратегічними, концептуальними, доктринальними та іншими документами у сфері безпеки і оборони; вивчення проблем досягнення визначених воєнно-політичних і воєнно-стратегічних цілей, шляхів і способів їх вирішення; формування комплексу заходів із розв'язання цих та інших проблем.

Такий аналіз може об'єднувати процеси визначення:

концептуального бачення проблеми щодо формулювання вимог до спроможностей та їх досягнення, яке може реалізовуватись за схемою: проблема, прогнозований кінцевий результат (ціль), шляхи досягнення результату, сплановані сили і засоби для забезпечення досягнення кінцевого результату;

переліку заходів, які необхідно виконати для забезпечення розвитку та функціонування спроможностей, або як реалізувати шляхи досягнення необхідних спроможностей, які визначаються під час розроблення концептуального бачення;

структур спроможностей (груп спроможностей), детального переліку завдань i підзавдань спроможностей, які визначені для 
оцінювання, кінцевих результатів, умов виконання тощо.

Слід зазначити, що для аналізу вимог вкрай важливим $є$ опис майбутнього безпекового середовища навколо України [8].

На основі вимог мають бути визначені спроможності, які необхідно мати складовим сил оборони в цілому, або за окремими їх складовими для адекватного реагування на існуючі та потенційні виклики i загрози в межах фінансових асигнувань, які виділяються на їх утримання, нарощування, формування та позбавлення від непридатних для застосування.

Аналіз

недоліків/проблем

може здійснюватися за функціональними сферами впливу на спроможності, 3 урахуванням факторів впливу на їх формування. Вважається, що недоліки/проблеми можуть існувати у трьох основних сферах впливу на спроможності:

контролюючі фактори, що регулюють процес виконання завдань - національне законодавство, політика оборонного планування, бюджетні кошти тощо;

вихідні ресурси, які необхідні для виконання завдання, а саме: особовий склад, матеріально-технічне забезпечення сил оборони, сировина/матеріали, технології виготовлення ОВТ для підтримки сфери оборони та інше;

механізми, що визначають структури (організації), які фактично виконують завдання, пов'язані зі спроможністю. Вони включають: персонал; організацію; процеси, які визначають спроможність та інструменти, що дають змогу виконати завдання.

Процес виявлення проблем/недоліків пов’ язаний із:

спроможністю - оцінюється ступінь здатності або нездатності досягти необхідного ефекту у визначених умовах виконання завдань;

складом i чисельністю військ (сил), обсягом ресурсів та можливістю або неможливістю їх залучення для виконання визначених завдань;

терміном експлуатації: необхідність у заміні через старіння зразків ОВТ, матеріально-технічних та інших засобів; завершення їх життєвого циклу;

технологічним старінням ОВТ тощо;

політичним обмеженням, яке пов'язане 3 неможливістю, за потребою, використати сили оборони через обмеження, які встановлені міжнародним правом або законодавством.
Елементи

недоліків/проблем мають бути:

пов'язаними 3 визначеними завданнями

щодо застосування сил оборони та їх розвитку; специфічними, що обумовлені визначенням окремих структурних підрозділів, інструментів, політики оборонного планування тощо, які $є$ недостатніми або відсутніми, i мають вплив на виконання завдання у визначених умовах обстановки. Ці недоліки/проблеми мають бути обгрунтованим і об'єктивно необхідними для розвитку та/або набуття відповідних спроможностей;

сфокусованими на одній проблемі щодо вирішення кількох завдань у відповідних умовах обстановки 3 обов'язковим дотриманням визначених стандартів.

Загалом формування недоліків/проблем має здійснюватися системно у сукупності цих та інших елементів. Під час визначення недоліків/проблем можуть використовуватися такі форми і способи аналізу:

опитування за

допомогою

безпосереднього спілкування, дистанційно у форматі аудиторного письмового опитування, через засоби зв'язку, телекомунікацій в електронному форматі та іншими способами. До того ж, було б доцільним розроблення запитальників, що могло б сприяти усуненню непорозумінь i налагодженню ефективнішої взаємодії між суб'єктами планування;

розроблення сценарію, що передбачає під час визначення недоліків/проблем комплексу дій у різних ситуаціях та умовах середовища безпеки;

інтерв'ю, яке можна провести у форматі співбесіди серед профільних фахівців або людей і відповідним досвідом тощо;

огляд літературних джерел, статей, вивчення документів, аналізу звітів про стан структур/організацій, які визначені для оцінювання;

узагальнення досвіду проведених операцій (бойових дій) у рамках проведення АТО, операцій об’єднаних сил, участі у операціях 3 підтримки миру i безпеки, підготовки військ (сил), висновки наукових досліджень у проведенні військових навчань тощо;

аналіз висновків старших командирів (керівників), які сфокусовані на визначенні та пріоритетності розв' язання недоліків/проблем.

3a результатами аналізу недоліків/проблем розробляється відповідний звіт, який може використовуватися як основа для прийняття рішень. 
Аналіз рішень здійснюється відповідно до категорій базових елементів спроможностей. $\mathrm{y}$ рішеннях доцільно вказувати організацію, у якій здійснюватиметься їх впровадження, та очікуваний результат.

На основі аналізу рішень готуються рекомендації/пропозиції, які мають відповідати таким критеріям:

відповідність/придатність,

що забезпечує мінімізацію або усунення недоліків, або розв'язання проблем;

реалістичність/доцільність, що визначає можливість реалізувати рекомендації належним чином;

прийнятність, що забезпечує сприйняття цих рекомендацій зацікавленими сторонами.

Загалом

зазначені рекомендації/пропозиції щодо розв'язання проблем або усунення недоліків/проблем направлені на: підтримання наявних спроможностей; нарощування (удосконалення) базових компонентів (складових) спроможностей; формування нових спроможностей; позбавлення від надлишкових спроможностей.

Таким чином зазначені рекомендації/пропозиції $є$ результатом аналізу рішень. Вони оформлюються у формі звіту про розроблені проекти управлінських рішень, які надалі можуть бути підставою внесення їх у документи 3 розвитку спроможностей складових сил оборони.

За результатами аналізу рішень доречно відпрацювати Імплементаційний план, у якому можуть міститися:

рекомендації/пропозиції, які $\epsilon$ специфічними та сфокусованими на одній проблемі/недоліку і оформлені, як правило, у формі - одна проблема - одна рекомендація/пропозиція;

організація/структура, яка визначена відповідальною за впровадження (фінансування) рекомендацій/пропозицій;

терміни/строки або дата завершення виконання рекомендацій/пропозицій;

зв'язки, які визначають послідовність та пріоритетність виконання. Наприклад, політика оборонного планування має бути визначена перед відпрацюванням проектів стратегій, програм, планів тощо;

обсяг ресурсів для впровадження рекомендацій/пропозицій. Якщо реалізація рекомендації/пропозиції потребує бюджетних видатків, то це має бути прописано у відповідних бюджетних програмах 3 визначенням відповідальних за фінансування.
На остаточному етапі оцінювання спроможностей готується загальний звіт і розробляються/уточнюються документи розвитку спроможностей, зокрема: Цільовий пакет спроможностей сил оборони та плани розвитку спроможностей складових сил оборони.

Для системного аналізу пропозицій за результатами оцінювання, розгляду фаховими експертами та здійснення менеджменту реалізації прийнятих рішень в органах управління складових сил оборони доцільно створювати систему управління оцінювання та розвитку спроможностей. Вона має об'єднувати у собі керівництво; структурні підрозділи та експертів на постійній або тимчасовій основі. Ключовими фігурантами такої системи призначаються: керівник, секретар, рецензент, менеджер. Також можуть бути створені дорадчі групи, групи 3 визначення пріоритетів, супроводження та оцінювання реалізації спроможностей тощо.

Висновок. Розпочате реформування системи оборонного планування в України відповідно до принципів оборонного планування у державах-членах НАТО потребує перебудови системи оборонного планування в органах управління складових сил оборони.

Запропоновані авторами методичні підходи щодо здійснення процедури оцінки спроможностей у межах оборонного планування на основі спроможностей дадуть змогу урахувати вітчизняний досвід оборонного планування, адаптувати методологію оцінювання спроможностей, яка застосовується в державах-членах НАТО, до національних особливостей України та підвищити ефективність системи оборонного планування у складових сил оборони та використання оборонних ресурсів для набуття спроможностей.

Перспективою подальших досліджень 3 урахуванням отриманих результатів $\epsilon$ подальше удосконалення методології оцінювання спроможностей як складової оборонного планування на основі спроможностей для складових сил оборони.

\section{СПИСОК ВИКОРИСТАНОЇ ЛІТЕРАТУРИ}

1. Закон України "Про національну безпеку України" від 21 червня 2018 року № 2469-VIII // Відомості Верховної Ради України. - 2018.

2. Указ Президента України від 6 червня 2016 року № 240/2016 "Про рішення Ради національної безпеки i оборони України від 20 травня 
2016 року "Про стратегічний оборонний бюлетень України”.

3. Рекомендації з оборонного планування на основі спроможностей в Міністерстві оборони та Збройних Силах України, затверджені Міністром оборони України 13.06.2017 р. № 5789/3/3.

4. Рекомендації 3 порядку організації проведення оцінювання спроможностей у Збройних Силах України, затверджені Міністром оборони України від 07.12.2017 p.

5. Крикун П. М., Павленко В. І., Кравчук В. В. Розвиток оборонного планування як складової національної системи планування у сфері безпеки i оборони за умов наближення до процедур i стандартів НАТО. // Збірник наукових праць ЦВСД НУОУ. - К., 2017. - № 2 (60), С. 44-48.

6. Сектор безпеки і оборони: стратегічне планування / В. Ф. Саганюк, М. М. Лобко, О .В. Устименко, А. К. Павліковський; за ред.. Р. І. Тимошенка. - К.: Майстер книг, 2016 - 148 с.
7. Дєнєжкін М. М., Наливайко А. Д., Поляєв А. І. Особливості оборонного планування у державахчленах НАТО, на основі спроможностей. // Збірник наукових праць ЦВСД НУОУ. - К., 2017. - № 2 (60), С. 34-38.

8. Крикун П. М., Павленко В.І ., Полякова О. В. Стандарти планування. // Оборонний вісник. Центр воєнної політики та політики безпеки, К. № 7, 2018. - С. 4-11.

9. Крикун П. М., Павленко В. І., Полякова О. В. Алгоритм безпеки. // Оборонний вісник. Центр воєнної політики та політики безпеки, К. - № 2, 2018. - С. 4-7.

10. Корендович В. С., Наливайко А. Д., Поляєв А. І. Підходи до створення та функціонування системи управління вимогами щодо розвитку спроможностей в органах управління складових сил оборони. // Збірник наукових праць ЦВСД НУОУ імені Івана Черняховського”. - К., 2018. № 1 (62). - С. 51-56.

Стаття надійшла до редакційної колегії 04.02.2019

\section{Крикун П. М.;}

Наливайко А. Д., к.т.н., доцент;

Поляев А. И.

Центр военно-стратегических исследований Национального университета обороны Украины имени Ивана Черняховского, Киев

\section{О внедрении в оборонное планирование сил обороны современной методологии оценки возможностей}

Резюме. В статье рассмотрены возможные подходы к осуществлению процедуры оценки возможностей составляющих сил обороны в рамках оборонного планирования на основе возможностей с учетом отечественного опыта оборонного планирования и опыта государств-членов НАТО.

Ключевые слова: оборонное планирование на основе возможностей; оценка возможностей; базовые элементы (составляющие) возможностей; система управления требованиями.

\section{P. Krikun;}

\section{A. Nalyvayko, PhD (Technical), associate professor;}

\section{A. Polyaev}

Center for Military and Strategic Studies of the National Defence University of Ukraine named after Ivan Cherniakhovskyi, Kyiv

\section{Implementation of the modern methodology for assessing capabilities in the defense} planning components of the defense forces

Resume. The article discusses possible approaches to the assessment of capabilities of defense forces constituents within the framework of defense planning on the basis of capabilities, taking into account national defense planning experience and experience of NATO member states.

Keywords: defense planning capabilities; capacity assessment; basic elements (components) of capabilities; requirements management system. 